\title{
Using an individual-based model to inform estuary management in the Baie de Somme, France
}

\author{
Sarah E.A. Le V. dit Durell, Richard A. Stillman, Patrick Triplet, Michel Desprez \\ Cédric Fagot, Nicolas Loquet, François Sueur and John D. Goss-Custard
}

\begin{abstract}
Conservation managers need to be able to assess and prioritize issues that may affect their target habitats and species. In the Baie de Somme, France, conservation issues affecting overwintering shorebirds include hunting pressure, cockle fishing, recreational disturbance, Spartina encroachment, and changing sediment levels. We used an individual-based model to predict the effect of these issues on the survival of three shorebird species: dunlin Calidris alpina, oystercatcher Haematopus ostralegus and curlew Numenius arquata. In the model, removing hunting from the mudflats in the eastern part of the estuary had the greatest positive effect on shorebird survival. Oystercatcher survival decreased markedly when stocks of large cockles were reduced to $<250 \mathrm{~m}^{-2}$ or numbers of fishermen per day were doubled. Short-term disturbance events, such as walkers, had more effect on shorebird survival than longterm events, such as fishermen. Dunlin, as a protected species, were able to feed outside the Réserve Naturelle and were unaffected by disturbance within the Réserve. Oystercatcher survival decreased when the number of disturbance events within the Réserve exceeded one $h^{-1}$, and curlew survival when disturbance events exceeded six $\mathrm{h}^{-1}$. Spartina encroachment caused dunlin survival to decline steadily as feeding habitat was lost. Dunlin were also the species most affected by changes in sediment levels, likely to occur through either sedimentation or sea level rise.
\end{abstract}

Keywords Baie de Somme, estuary management, France, individual-based model, overwinter survival, shorebirds.

Sarah E.A. Le V. Dit DurelL* (Corresponding author), Richard A. Stillman $^{\dagger}$ and John D. Goss-Custard Centre for Ecology and Hydrology Dorset, Winfrith Technology Centre, Dorchester, Dorset, DT2 8ZD, UK. E-mail seadurell@tiscali.co.uk

Patrick Triplet SMACOPI, 1 Place de l'Amiral Courbet, F-80100 Abbeville, France.

Nicolas Loquet and Michel Desprez GEMEL, 115 Quai Jeanne d'Arc, 80230 Saint-Valery/Somme, France.

François Sueur and CÉDric Fagot Groupe Ornithologique Picard, 80120 St Quentin en Tourmont, France.

${ }^{*}$ Current address: 30 Bestwall Road, Wareham, Dorset, BH20 4JA, UK.

${ }^{\dagger}$ Current address: School of Conservation Sciences, Bournemouth University, Talbot Campus, Poole, Dorset, BH12 5BB, UK.

Received 21 July 2006. Revision requested 15 December 2006.

Accepted 30 April 2007.

\section{Introduction}

Tntertidal estuaries in north-west Europe provide essen1 tial feeding grounds for internationally important numbers of overwintering shorebirds (Stroud et al., 1990; Davidson et al., 1991). As a result, most estuaries in northwest Europe have been designated Special Protection Areas and European Marine Sites under the European Union Directive 79/409/EEC for the conservation of wild birds. Statutory bodies and managers of these sites have to be able to monitor the quality of their sites for particular bird species and to assess how potential changes may affect site quality. Conservation managers also need to understand how changes in the area and quality of habitats within estuaries will affect numbers of overwintering shorebirds.

Estuary managers throughout north-west Europe have always had to deal with conflicts between conservation interests and human activities such as waste disposal, land claim, shellfisheries and recreation. In recent years they have also had to consider the effects of climate change, particularly sea-level rise. Modelling of estuarine systems can help managers and policy makers focus their attentions on the most important issues. To this end, individual-based models have been developed to assess estuary Special Protection Area quality (Stillman et al., 2005a,b; West et al., 2005), to predict the effect of habitat loss and habitat change on shorebird overwinter survival (Durell et al., 2005b, 2006), and to advise on shellfishery management (Stillman et al., 2001; West et al., 2003; Caldow et al., 2004).

In this study we use a newly developed individual-based model to predict the effect of management options on the overwinter survival of three shorebird species in the Baie de Somme, northern France. The Baie de Somme is the second largest estuary on the French channel coast and is designated a RAMSAR waterfowl habitat site and a marine Special Protection Area. A major consideration for the protection of overwintering shorebirds in the Baie de Somme is that, apart from within the Réserve Naturelle in the north-west, hunting is allowed on the intertidal flats and several shorebird species are legitimate prey. This means that, during the hunting season, most shorebirds feed within the Réserve Naturelle. However, it also means that, if food supplies become severely depleted within the Réserve, starving birds have the chance of replenishing their reserves in the hunted area. Individual-based modelling can simulate the decisions that the birds have to take when deciding where to feed. 
The Baie de Somme is a major macrotidal estuary (mean tidal range $8.98 \mathrm{~m}$ ) with a wide entrance exposed to prevailing westerly currents and south-westerly winds. As a result, the estuary is subject to substantial processes of deposition and erosion of sediment (McClusky et al., 1994). The intertidal flats range from sandy muds to mobile sands and, in the lower reaches of the estuary, there are substantial cockle Cerastoderma edule beds that are fished commercially (Desprez, 1995). As well as hunting, management issues considered in this study are cockle fishing and recreational disturbance within the Réserve Naturelle, Spartina encroachment of upshore feeding areas, and changing sediment levels as a result of sedimentation or sea-level rise.

\section{Methods}

\section{The model}

The individual-based model used in this study, MORPH, is described in Durell et al. (2006). In summary, the model simulates how individual birds obtain their daily food requirements throughout the winter and predicts how many will survive in good condition for migration to the breeding grounds in the spring. The food supply available for the birds is distributed over a number of discrete patches, each of which may differ in area and in the time that food is exposed during the tidal cycle. The patches may also differ in the type (prey species), quantity (prey species' abundance) and quality (size and energy content of prey species) of food available. To apply the model to any estuary, therefore, data are needed on the number of birds present at the start of the winter and the area, exposure time and the macrobenthic fauna of all the habitat patches found in that estuary. Local daily tide heights and daily mean temperatures are also required.

\section{Model patches}

Shorebird macrobenthic invertebrate prey were sampled in the Baie de Somme at monthly intervals throughout the winter of 2001-2002, using a grid system (for methods see Durell et al., 2005a). Intertidal patches were defined by their invertebrate communities, their sediment type, their geographical position and whether they were in the Réserve Naturelle or not. This resulted in nine different feeding patches within the model (Fig. 1). Only intertidal areas are used for feeding by shorebirds in the Baie de Somme because of hunting pressure in adjacent terrestrial habitats. At high tide, birds roost in the Parc Ornithologique, which is part of the Réserve Naturelle (Fig. 1).

Patch variables included in the model, and the baseline values used, are shown in Table 1. Mean patch heights allow the model to compute the time for which patches are uncovered by the tide in each tidal cycle and so are available for feeding. Patch heights were calculated using

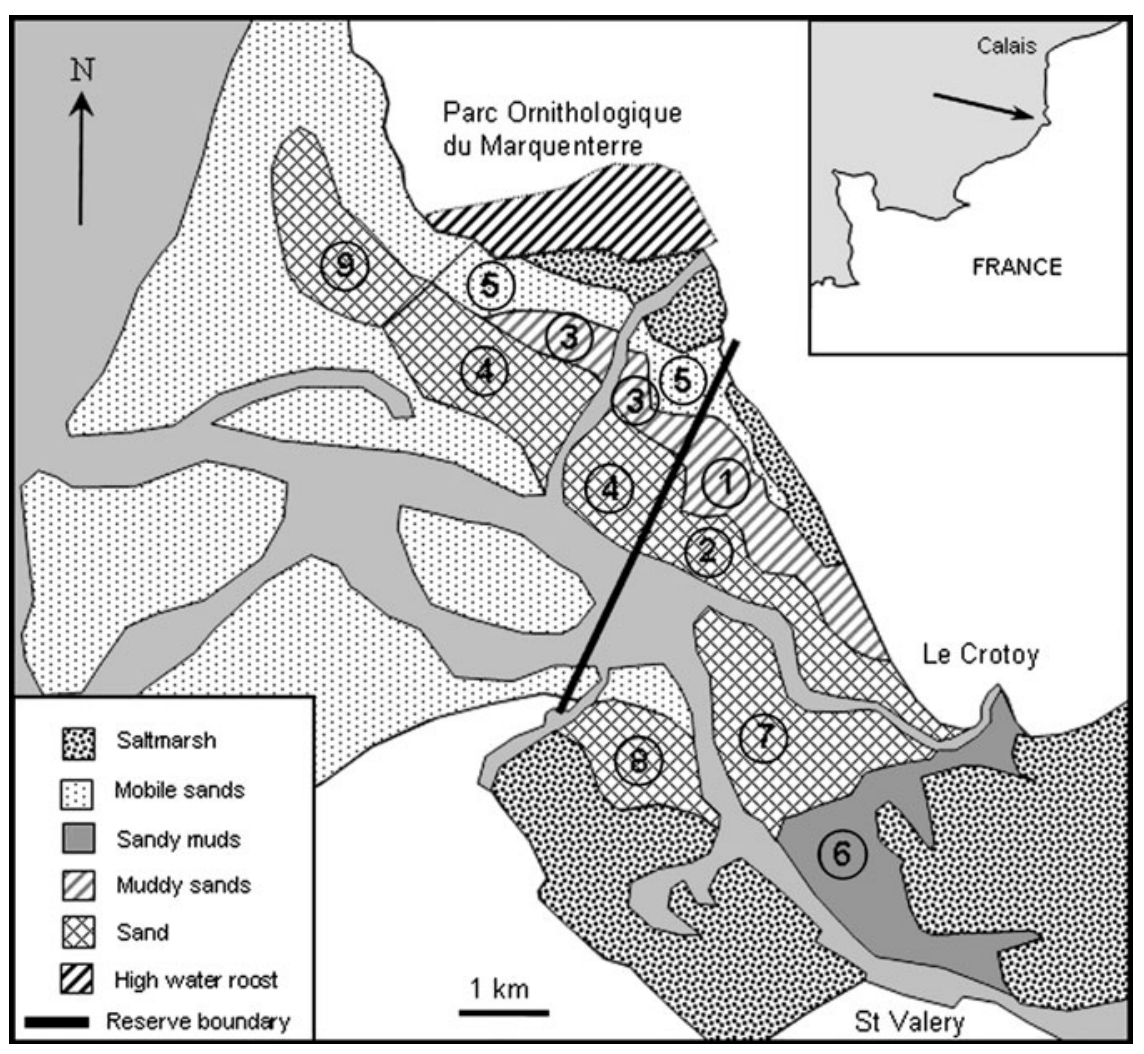

FIg. 1 The Baie de Somme (with position in France shown on inset). Numbers show feeding patches used in the model, defined by invertebrate community, sediment type and geographical position. For patch names, see Table 1. 
TABLE 1 Patch variables used in the Baie de Somme model (see text for details). Patch numbers correspond to those in Fig. 1.

\begin{tabular}{|c|c|c|c|c|c|c|c|c|c|c|}
\hline \multirow{2}{*}{ Patch variables } & & \multicolumn{9}{|l|}{ Patch name } \\
\hline & & 1. Crothaut & 2. Crotbas & 3. Reshaut & 4. Resbas & 5. Rescaren & 6. Chassehaut & 7. Chassebas & 8. Sud & 9. St Quentin \\
\hline \multicolumn{2}{|l|}{ Patch area $\left(\mathrm{m}^{2}\right)$} & $2,110,000$ & $1,070,000$ & 940,000 & $2,750,000$ & $1,570,000$ & $1,590,000$ & $3,200,000$ & $1,540,000$ & $1,300,000$ \\
\hline \multicolumn{2}{|c|}{ Exposure tide height (m) } & 7.5 & 7.1 & 8 & 7.3 & 8.6 & 7.1 & 6 & 6.4 & 5.6 \\
\hline \multirow[t]{4}{*}{ Disturbers $\left(\mathrm{h}^{-1}\right)$} & weekend day & $0-2$ & $0-2$ & $0.3-1.8$ & $0.3-1.8$ & $0.3-1.8$ & $0-2$ & $0-2$ & $0-2$ & $0-2$ \\
\hline & weekend night & 0 & 0 & 0 & 0 & 0 & 0 & 0 & 0 & 0 \\
\hline & weekday day & $0-1$ & $0-1$ & $0.2-0.8$ & $0.2-0.8$ & $0.2-0.8$ & $0-1$ & $0-1$ & $0-1$ & 0 \\
\hline & weekday night & 0 & 0 & 0 & 0 & 0 & 0 & 0 & 0 & 0 \\
\hline \multirow{4}{*}{$\begin{array}{l}\text { Hunters }\left(\mathrm{h}^{-1}\right) \\
\text { (1 Sept.-31 Jan.) }\end{array}$} & weekend day & $3-6$ & $1.5-3$ & 0 & 0 & 0 & $1.5-3$ & $6-12$ & $3-6$ & 0 \\
\hline & weekend night & $0-2$ & $0-1$ & 0 & 0 & 0 & $0-1$ & $0-4$ & $0-2$ & 0 \\
\hline & weekday day & $2-3$ & $1-1.5$ & 0 & 0 & 0 & $1-1.5$ & $4-6$ & $2-3$ & 0 \\
\hline & weekday night & $0-1$ & $0-0.5$ & 0 & 0 & 0 & $0-0.5$ & $0-2$ & $0-1$ & 0 \\
\hline \multirow[t]{4}{*}{ Fishermen $\left(h^{-1}\right)$} & weekend day & 0 & 0 & 0 & 0 & 0 & 0 & 0 & 0 & 0 \\
\hline & weekend night & 0 & 0 & 0 & 0 & 0 & 0 & 0 & 0 & 0 \\
\hline & weekday day & 0 & 0 & $0-5$ & $51-88$ & 0 & 0 & 0 & 0 & $24-42$ \\
\hline & weekday night & 0 & 0 & 0 & 0 & 0 & 0 & 0 & 0 & 0 \\
\hline \multirow[t]{4}{*}{ Raptors $\left(\mathrm{h}^{-1}\right)$} & weekend day & $0-0.7$ & $0-0.7$ & $0-0.7$ & $0-0.7$ & $0-0.7$ & $0-0.7$ & $0-0.7$ & $0-0.7$ & $0-0.7$ \\
\hline & weekend night & 0 & 0 & 0 & 0 & 0 & 0 & 0 & 0 & 0 \\
\hline & weekday day & $0-0.7$ & $0-0.7$ & $0-0.7$ & $0-0.7$ & $0-0.7$ & $0-0.7$ & $0-0.7$ & $0-0.7$ & $0-0.7$ \\
\hline & weekday night & 0 & 0 & 0 & 0 & 0 & 0 & 0 & 0 & 0 \\
\hline
\end{tabular}


topographical data from 1992 (Sogreah/EDF, 1995). These data consisted of heights for 3,600 points covering the whole estuary. Mean patch height was calculated by the geostatistical software Surfer (Golden Software, Golden, USA) from grid files using kriging as the gridding method.

Disturbers were considered to be any human source of disturbance that affected the birds but had no impact on their prey. Levels of disturbance were calculated from data collected during the bird surveys and from previous work (Triplet et al., 1999, 2003). Fishermen were commercial cockle harvesters who were not only potential sources of disturbance but also had an impact on prey densities. Hunters and raptors were a source of disturbance and also a potential mortality risk. Data on hunters and fishers were obtained from a literature search (P. Triplet, unpubl. data). Data on raptors were not available, and therefore raptor frequencies were estimations based on casual observation (P. Triplet, unpubl. data).

Prey types and size classes used in the model, and their initial densities, are given in Table 2. Prey densities used were from an October 2001 estuary-wide macrobenthic invertebrate survey. Non-bird winter prey mortality was calculated from the differences in prey densities at the end of a model run compared with densities found in March 2002 (Stillman et al., 2005b). Fishing loss was calculated from the licensed catch of $100 \mathrm{~kg}$ cockles per fisherman per day. Initial values of ash free dry mass (AFDM) for each resource, and the change in AFDM over the winter period, were measured from subsamples of invertebrates collected in each monthly survey (for methods see Durell et al., 2005a).

\section{Model foragers}

Three species of shorebirds were included in the model: dunlin Calidris alpina, oystercatcher Haematopus ostralegus and curlew Numenius arquata. These are the three most numerous shorebirds in the Baie de Somme, being present in nationally important numbers (Sueur \& Triplet, 1999). Low tide bird counts were made at 10-day intervals from September 2001 until March 2002. Data recorded during these surveys included the numbers of birds feeding or resting, prey items taken and the number and source of disturbances taking place during each recording period.

Forager numbers, diets, constants and variables used in the model are given in Table 3. Forager numbers used in the model were based on high water count data for 1993-2002. Forager diets were determined from literature searches and observations of feeding birds during low water counts. For a detailed explanation of forager constants and variables, and how forager energy intake and expenditure are calculated, see Durell et al. (2006). Full details of how the shorebird functional response equations were derived are also given in Goss-Custard et al. (2006b).
Three sources of forager mortality were included in the model: starvation, predation and being shot. A forager died (or emigrated) if it failed to maintain any fat reserves, i.e. body mass $\leq$ starvation mass. The starvation mass of each species was taken from previous studies or predicted from basal body mass. Dunlin were the only birds with a risk of being predated if raptors were present (Cresswell \& Whitfield, 1994). However, as a protected species, dunlin had no risk of being shot. Both oystercatchers and curlew are shot by hunters in the Baie de Somme and the probability of being shot was calculated from the numbers of birds recorded as shot each winter (P. Triplet, unpubl. data). Oystercatchers and curlew new to the estuary in autumn took 1 day to learn that they were at risk of being shot in the hunting areas. After this, they avoided hunted areas unless they were close to starvation (reserves $\leq 8 \%$ of total body mass), in which case they risked feeding within the hunted area and the chance of being shot.

\section{Model calibration}

Although forager starvation rates on the Baie de Somme were unknown, they are likely to be within the range of 2$10 \%$ (Cramp \& Simmons, 1983). Without calibration, overwinter starvation rates for all three shorebirds in the model were zero. We therefore used night-time feeding efficiency, about which little is known, to calibrate the model such that starvation rates were above zero. We did this by systematically reducing night-time feeding efficiency for each species until some birds had died by the end of the winter. This was achieved when night-time feeding efficiency was 0.90 for dunlin and 0.70 for oystercatchers and curlew.

\section{Model validation}

One test of the model is to see how well it predicts the birds' distribution around the estuary. We compared the distribution of birds in the model between October and January with mean low water and tide receding/tide advancing counts made during the winter of 2001-2002. Another test of the model is to compare the proportion of time that birds spend feeding during the tidal cycle. We compared model output for the low tide period in daylight with data collected on bird feeding activity throughout the winter.

\section{Simulation procedure}

Each model run was for one winter. As the predictions of the model vary each time it is run, because of the particular characteristics of the individuals in each run, we ran 10 simulations for each combination of parameter values and present the mean prediction with associated 95\% confidence limits. The main output from each set of simulations was shorebird overwinter survival. 
TABLE 2 Resource variables used in the Baie de Somme model, with size class, initial densities in each patch (patch numbers correspond to those in Fig. 1), winter mortality, fishing loss and resource component.

\begin{tabular}{|c|c|c|c|c|c|c|c|c|c|c|c|c|c|c|}
\hline \multicolumn{2}{|l|}{ Resource } & \multicolumn{9}{|c|}{ Initial density $\left(\right.$ no. $\mathrm{m}^{-2}$ ) } & \multirow{2}{*}{$\begin{array}{l}\text { Winter } \\
\text { mortality } \\
(\%)\end{array}$} & \multirow{2}{*}{$\begin{array}{l}\text { Fishing } \\
\text { loss (no. } \\
\text { fisher }{ }^{-1} \mathrm{~d}^{-1} \text { ) }\end{array}$} & \multicolumn{2}{|c|}{ Resource component } \\
\hline Species & $\begin{array}{l}\text { Size class } \\
(\mathrm{mm})\end{array}$ & $\begin{array}{c}1 . \\
\text { Crothaut }\end{array}$ & $\begin{array}{c}2 . \\
\text { Crotbas }\end{array}$ & $\begin{array}{c}3 . \\
\text { Reshaut }\end{array}$ & $\begin{array}{c}4 . \\
\text { Resbas }\end{array}$ & $\begin{array}{c}5 . \\
\text { Rescaren }\end{array}$ & $\begin{array}{c}6 . \\
\text { Chassehaut }\end{array}$ & $\begin{array}{c}7 . \\
\text { Chassebas }\end{array}$ & $\begin{array}{l}8 . \\
\text { Sud }\end{array}$ & $\begin{array}{c}9 . \\
\text { St Quentin }\end{array}$ & & & $\begin{array}{l}\text { Initial } \\
\operatorname{AFDM}^{*}(\mathrm{~g})\end{array}$ & $\begin{array}{l}\text { Overwinter } \\
\text { change (\%) }\end{array}$ \\
\hline Cockles & $5-9.99$ & $1,568.72$ & 41 & 462 & 3,471 & 0 & 0 & 0 & 1,817 & 113 & 79 & 0 & 0.003945 & -11 \\
\hline Cockles & $10-14.99$ & $1,515.88$ & 1,126 & 1,062 & 7,455 & 0 & 0 & 0 & 3,133 & 559 & 51 & 0 & 0.018061 & -15 \\
\hline Cockles & $15-19.99$ & 103.55 & 337 & 336 & 376 & 0 & 0 & 0 & 50 & 260 & 10 & 0 & 0.049196 & -17 \\
\hline Cockles & $20-24.99$ & 66.67 & 32 & 87 & 39 & 0 & 0 & 0 & 200 & 32.4 & 10 & 0 & 0.103988 & -19 \\
\hline Cockles & $25-29.99$ & 25.36 & 8 & 36 & 61 & 0 & 0 & 0 & 33 & 81.8 & 25 & 433 & 0.189032 & -21 \\
\hline Cockles & $30-34.99$ & 0 & 0 & 19 & 11 & 0 & 0 & 0 & 0 & 58.1 & 25 & 433 & 0.310886 & -22 \\
\hline Cockles & $35-39.99$ & 0 & 0 & 0 & 0 & 0 & 0 & 0 & 0 & 15.2 & 25 & 433 & 0.476089 & -23 \\
\hline Macoma & $5-9.99$ & 1149 & 88 & 29 & 382 & 0 & 0 & 4,383 & 4,383 & 0 & 58 & 0 & 0.005162 & -3 \\
\hline Macoma & $10-14.99$ & 395 & 217 & 117 & 72 & 0 & 0 & 83 & 83 & 0 & 22 & 0 & 0.021927 & -26 \\
\hline Macoma & $15-19.99$ & 871 & 244 & 213 & 427 & 0 & 0 & 350 & 350 & 0 & 22 & 0 & 0.056847 & -38 \\
\hline Macoma & $20-24.99$ & 123 & 0 & 0 & 17 & 0 & 0 & 83 & 83 & 0 & 22 & 0 & 0.115805 & -45 \\
\hline Macoma & $25-29.99$ & 24 & 0 & 0 & 0 & 0 & 0 & 0 & 0 & 0 & 22 & 0 & 0.204397 & -51 \\
\hline Hydrobia & $3+$ & 30,407 & 0 & 7,307 & 20,083 & 0 & 0 & 0 & 42,213 & 0 & 87 & 0 & 0.001263 & 0 \\
\hline Worms & $2-3.99$ & 60.82 & 0 & 0 & 38.6 & 0 & 100 & 0 & 34 & 0 & 20 & 0 & 0.000136 & 0 \\
\hline Worms & $4-5.99$ & 196.28 & 0 & 23.93 & 221.4 & 0 & 450 & 0 & 167 & 0 & 20 & 0 & 0.001061 & 0 \\
\hline Worms & $6-7.99$ & 625.9 & 0 & 194.5 & 566.1 & 0 & 250 & 0 & 500 & 0 & 20 & 0 & 0.006274 & 0 \\
\hline Worms & $8-9.99$ & 226.77 & 0 & 156.38 & 544.8 & 0 & 50 & 0 & 333 & 0 & 20 & 0 & 0.023080 & 0 \\
\hline Worms & $10-11.99$ & 168.08 & 0 & 103.9 & 261.2 & 0 & 700 & 0 & 83 & 0 & 0 & 0 & 0.070963 & 0 \\
\hline Worms & $12-13.99$ & 86.88 & 0 & 50.88 & 22.18 & 0 & 350 & 0 & 34 & 0 & 0 & 0 & 0.175007 & 0 \\
\hline Worms & $14-15.99$ & 0 & 0 & 0 & 0 & 0 & 150 & 0 & 0 & 0 & 0 & 0 & 0.379800 & 0 \\
\hline Corophium & $3+$ & 0 & 0 & 0 & 0 & 8,107 & 16,017 & 0 & 0 & 0 & 0 & 0 & 0.000400 & 0 \\
\hline
\end{tabular}

${ }^{*}$ Ash free dry mass 
TABLE 3 Forager variables used in the Baie de Somme model (see text for details).

\begin{tabular}{|c|c|c|c|}
\hline Forager variables & Oystercatcher & Dunlin & Curlew \\
\hline Initial numbers & 7,000 & 6,500 & 1,000 \\
\hline Arrival dates & 1 Sept.-31 Oct. & 1 Sept.-31 Oct. & 1 Sept.-31 Oct. \\
\hline Departure dates & 14 Feb.-31 Mar. & 14 Feb.-31 Mar. & 14 Feb.-31 Mar. \\
\hline \multicolumn{4}{|l|}{ Diets } \\
\hline Small molluscs $(5-10 \mathrm{~mm}+$ Hydrobia $)$ & & $\mathrm{x}$ & \\
\hline Medium cockles (5-19.99 mm) & & & $\mathrm{x}$ \\
\hline Large cockles $(15-39.99 \mathrm{~mm})$ & $\mathrm{x}$ & & \\
\hline Large Macoma (10-29.99 mm) & $\mathrm{x}$ & & $\mathrm{x}$ \\
\hline Small worms $(2-7.99 \mathrm{~mm})$ & & $\mathrm{x}$ & \\
\hline Large worms $(4-15.99 \mathrm{~mm})$ & $\mathrm{x}$ & & $\mathrm{x}$ \\
\hline Corophium & & $\mathrm{x}$ & \\
\hline Range of foraging efficiencies (coef. of variation) & 0.125 & 0.125 & 0.125 \\
\hline Range of dominance values & $0-1$ & $0-1$ & $0-1$ \\
\hline Night-time feeding efficiency & 0.70 & 0.90 & 0.70 \\
\hline Lower critical temperature $\left(\mathrm{LCT},{ }^{\circ} \mathrm{C}\right)$ & 10.0 & 23.0 & 4.0 \\
\hline \multicolumn{4}{|l|}{ Mobile prey interference } \\
\hline Aggregation factor & 10 & 10 & 10 \\
\hline Threshold density (no. ha ${ }^{-1}$ ) & 100 & 100 & 100 \\
\hline Coefficients & $0.48,0,0$ & $0.48,0,0$ & $0.48,0,0$ \\
\hline \multicolumn{4}{|l|}{ Weak kleptoparasitism } \\
\hline Aggregation factor & 10 & 10 & 10 \\
\hline Threshold density (no. ha ${ }^{-1}$ ) & 100 & 100 & 100 \\
\hline Coefficients & $0.08,-0.08,0$ & $0.08,-0.08,0$ & $0.08,-0.08,0$ \\
\hline \multicolumn{4}{|l|}{ Large cockle kleptoparasitism } \\
\hline Aggregation factor & 10 & & \\
\hline Threshold density (no. ha ${ }^{-1}$ ) & 100 & & \\
\hline Coefficients & $0.50,-0.50,0$ & & \\
\hline \multicolumn{4}{|l|}{ Functional response } \\
\hline $\mathrm{B}_{50}\left(\mathrm{~g} \mathrm{AFDM}^{*} \mathrm{~m}^{-2}\right)$ & 0.761 & 0.761 & 0.761 \\
\hline Forager coefficient & -1.141162 & -1.712318 & -1.039356 \\
\hline Prey coefficient & 0.36542 & 0.36542 & 0.36542 \\
\hline Maximum rate of consumption $\left(\mathrm{kJ} \mathrm{d}^{-1}\right)$ & 1,300 & 265 & 1,952 \\
\hline \multicolumn{4}{|l|}{ Prey assimilation efficiency } \\
\hline Cockles and Macoma & 0.85 & 0.75 & 0.75 \\
\hline Worms & 0.75 & 0.75 & 0.75 \\
\hline Corophium & & 0.85 & \\
\hline Energy density of fat reserves $\left(\mathrm{kJ} \mathrm{g}^{-1}\right)$ & 33.4 & 33.4 & 33.4 \\
\hline Thermoneutral energy requirements $\left(\mathrm{kJ} \mathrm{d}^{-1}\right)$ & 757 & 132 & 997 \\
\hline Thermostatic costs below LCT $\left(\mathrm{kJ} \mathrm{deg}{ }^{-1} \mathrm{~d}^{-1}\right)$ & 31.8 & 1.5 & 42.1 \\
\hline \multicolumn{4}{|l|}{ Area affected by disturbance $\left(\mathrm{m}^{2}\right)$} \\
\hline Disturbers & 25,447 & 9,503 & 80,425 \\
\hline Hunters & 125,664 & 125,664 & 125,664 \\
\hline Fishers & 85,530 & 85,530 & 85,530 \\
\hline Energy cost of disturbance $(\mathrm{kJ})$ & 4.52 & 0.74 & 6.54 \\
\hline Time cost of disturbance (h) & 0.5 & 0.25 & 0.5 \\
\hline Probability of being shot (hunter ${ }^{-1}$ ) & 0.005 & 0 & 0.005 \\
\hline Probability of predation $\left(\right.$ raptor $\left.^{-1}\right)$ & 0 & 0.00001 & 0 \\
\hline Basal mass (g) & 500 & 48.8 & 757 \\
\hline Mean arrival weight $(\mathrm{g})$ & 484.2 & 47.3 & 881 \\
\hline Target weight $(\mathrm{g})$ & $484.2+\left(0.5971^{\star}\right.$ Day $)$ & $47.3+\left(0.1376^{\star}\right.$ Day $)-\left(0.00068^{\star} \mathrm{Day}^{2}\right)$ & 881 \\
\hline Starvation weight (g) & 350 & 39 & 489 \\
\hline
\end{tabular}

${ }^{*}$ Ash free dry mass 


\section{Management issues}

Hunting Hunting is a major leisure activity in the Baie de Somme, with over 3,000 licences being issued each season. The hunting season is 1 September-31 January and affects the whole estuary apart from the Réserve Naturelle. Oystercatchers and curlew are shot by hunters and all three shorebirds are affected by disturbance from hunting activity. In our simulations we explored the effect of reducing the area hunted on shorebird survival by removing hunting from (a) patches 1 and 2 in the north, (b) patch 8 in the south, and (c) patches 6 and 7 in the east of the estuary.

Cockle fishing The cockle beds in the Baie de Somme are all within the Réserve Naturelle. Cockle fishers not only disturb feeding birds, but also deplete their food supplies. We investigated the effect of varying cockle stocks on shorebird survival and the effect of varying the number of fishermen allowed on the cockle beds each day.

Disturbance The Réserve Naturelle is the only place where shorebirds can feed during the winter without the risk of being shot. It is also subject to disturbance, both from fishermen and from recreational visitors. We explored the effect of varying recreational disturbance rates within the Réserve to find out the threshold at which shorebird survival began to be affected. These disturbance events were in addition to any disturbances by fishermen and raptors and only took place during daylight hours.

Spartina encroachment Between 1995 and 2000 the area of cordgrass Spartina sp. in the Réserve Naturelle increased downshore at a rate of 20-40 $\mathrm{m} \mathrm{y}^{-1}$ (Triplet \& Rousseau, 2001). This has concerned the Réserve managers as they have found that Spartina encroachment removes dunlin feeding habitat ( $P$. Triplet, unpubl. data). Spartina marsh extends for approximately $5 \mathrm{~km}$ along the shore above model patches 1 and 5 (Fig. 1). An encroachment rate of $20 \mathrm{~m} \mathrm{y}^{-1}$ would therefore result in a loss of habitat of $10 \mathrm{ha}^{-1}$, and an encroachment rate of $40 \mathrm{~m} \mathrm{y}^{-1}$ a habitat loss of 20 ha $\mathrm{y}^{-1}$. In our simulations, we gradually reduced the area of patches 1 and 5 until these patches were completely removed, when habitat loss started affecting patch 3 . In this way, we could show how long it would take, if no measures were taken to prevent the present rate of increase in Spartina, before shorebird survival would be affected.

Changes in sediment levels Changes in sediment levels affect the length of time that inter-tidal habitats are available for
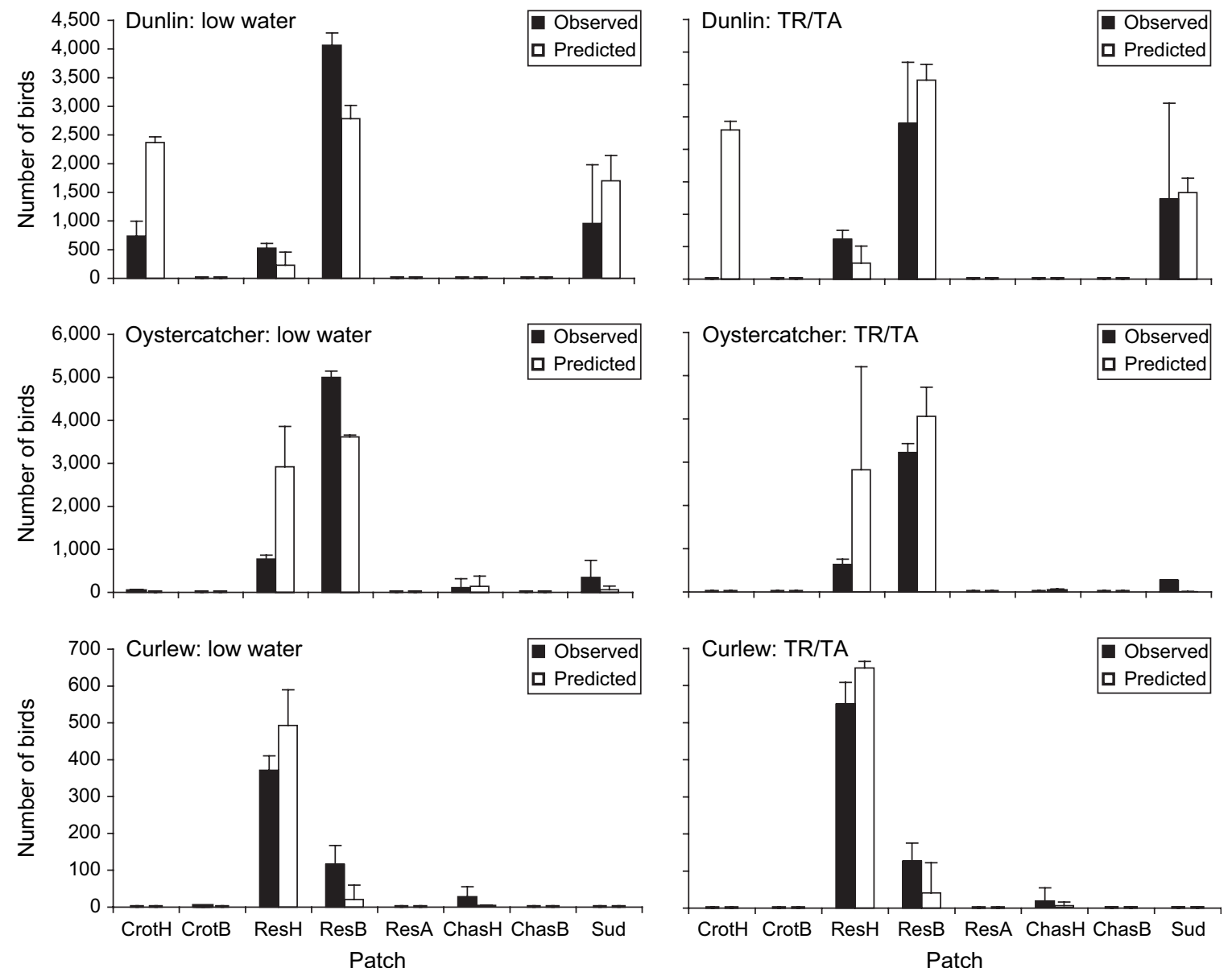

FIG. 2 Observed and model-predicted bird distributions during low water and tide receding/advancing (TR/TA). Bars are means with 95\% confidence limits. For full patch names, see Table 1. 
feeding birds. Sea level rise, for example, will reduce the amount of time that inter-tidal flats are exposed, with potentially severe consequences for shorebird survival (Durell et al., 2006). Changes in sediment levels also affect the invertebrate populations present. In the Baie de Somme, cockle stocks only occur between 6.7 and $8.4 \mathrm{~m}$ above spring low water level, with an optimum sediment height of $7.7 \mathrm{~m}$ (N. Loquet, unpubl. data). At the moment, sediments are accreting in the Baie de Somme, which means that the inter-tidal flats are becoming sandier and the shore level is rising. Between 1993 and 2001 accretion resulted in an average increase in sediment levels of $30 \mathrm{~cm}$, or $3.75 \mathrm{~cm} \mathrm{y}^{-1}$ (N. Loquet, unpubl. data). This means that accretion could counterbalance any effect of sea level rise. We explored the effect of both lowering and raising sediment levels. We did this by (a) varying patch height, and (b) removing all invertebrate prey except Corophium arenarium from a patch once its height exceeded $8.4 \mathrm{~m}$.

\section{Results}

The distribution of birds in the model at low water and tide receding/tide advancing matched with reasonable accuracy the observed distributions (Fig. 2). There was a significant and positive correlation between the observed and predicted distributions of all three species (Fig. 3). Moreover, regression intercepts did not differ significantly from zero (dunlin: $t=1.518, \mathrm{P}=0.26$; oystercatcher: $t=1.128, \mathrm{P}=$ 2.25; curlew: $t=1.267, \mathrm{P}=0.22$ ) and, for dunlin and oystercatchers, regression slopes did not differ significantly from unity (dunlin: $t=1.176, \mathrm{P}=0.26$; oystercatcher: $t=0.707, \mathrm{P}=0.49$ ). The regression slope for curlew was significantly different from unity $(t=2.873, \mathrm{P}=0.01)$, the main discrepancy being that more curlew were predicted to feed in the upshore part of the Réserve (Reshaut) than were observed (Fig. 2). The proportion of time that model birds spent feeding at low tide in daylight hours was also close to that observed for all three species throughout the winter (Fig. 4).

Increasing the area protected from hunting in the Baie de Somme significantly increased overwinter survival rates in oystercatchers and curlew (Fig. 5). Oystercatcher survival rates were higher whether the area protected from hunting was in the north, south or east part of the estuary. Curlew survival was unaffected if hunting was removed from the north or south sides, but increased dramatically if birds could feed in the eastern patches without being shot. Dunlin survival was not affected by any decrease in hunting area.

Neither varying cockle stocks nor varying the number of cockle fishermen had any effect on dunlin or curlew survival (Fig. 6). Oystercatcher survival was unaffected by any increase in cockle stocks but began to decrease markedly once the density of large cockles fell below $250 \mathrm{~m}^{-2}$ (Fig. 6a). Increasing the number of fishermen did affect oystercatcher
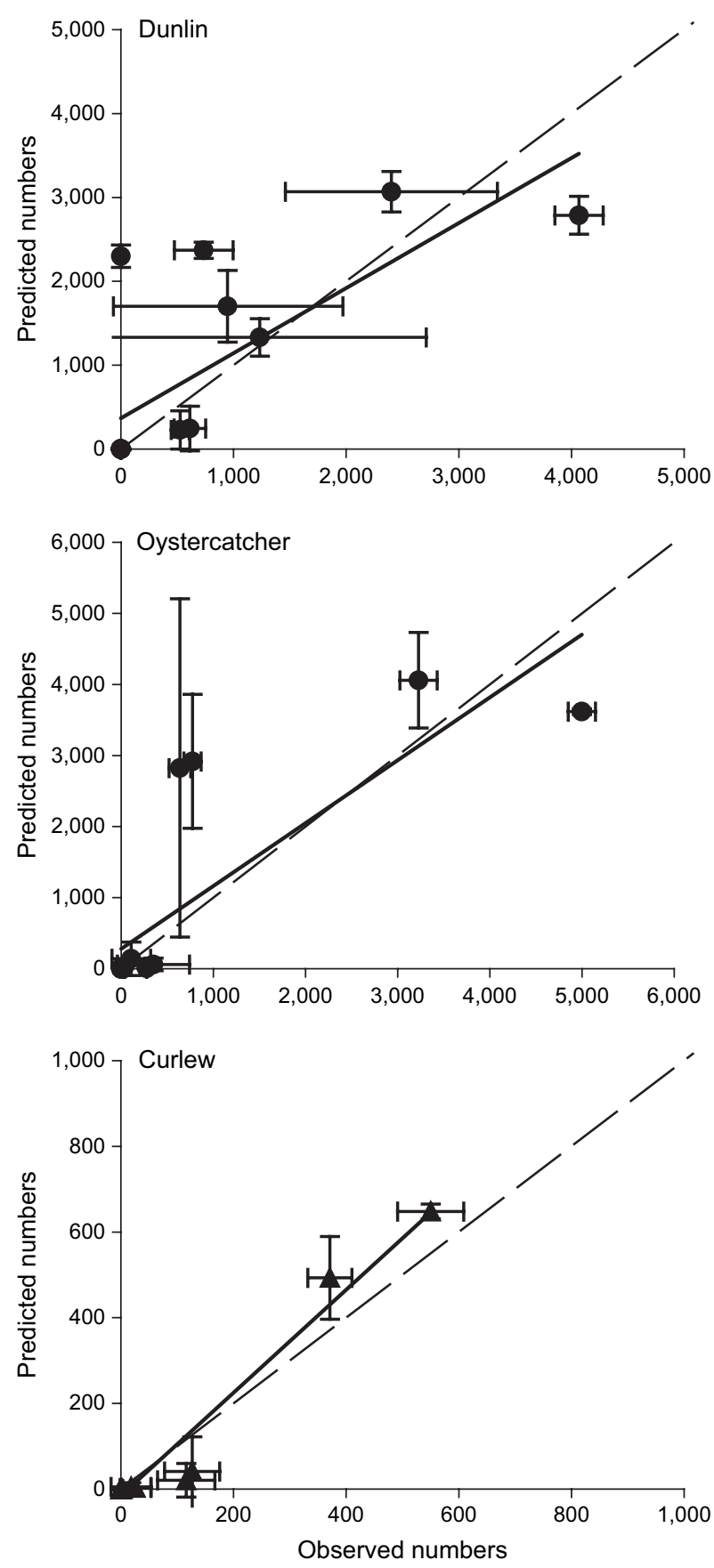

FIG. 3 Observed and model-predicted numbers of birds in each patch at low water and tide receding/tide advancing. Dashed lines show $\mathrm{x}=\mathrm{y}$. Error bars show 95\% confidence limits. Solid trendlines show linear regressions (dunlin predicted $=313 \pm$ $206+0.798 \pm 0.172 *$ observed; oystercatcher predicted $=278 \pm$ $246+0.885 \pm 0.162 *$ observed; curlew predicted $=-15.3 \pm 12.0+$ $1.2 \pm 0.07 *$ observed).

survival but only when the number exceeded 200, which is nearly double the current average of 105 fishermen day $^{-1}$ (Fig. 6b).

Increasing the rate of recreational disturbance within the Réserve Naturelle had a significant effect on oystercatcher and curlew survival rates (Fig. 7). Curlew survival began to 

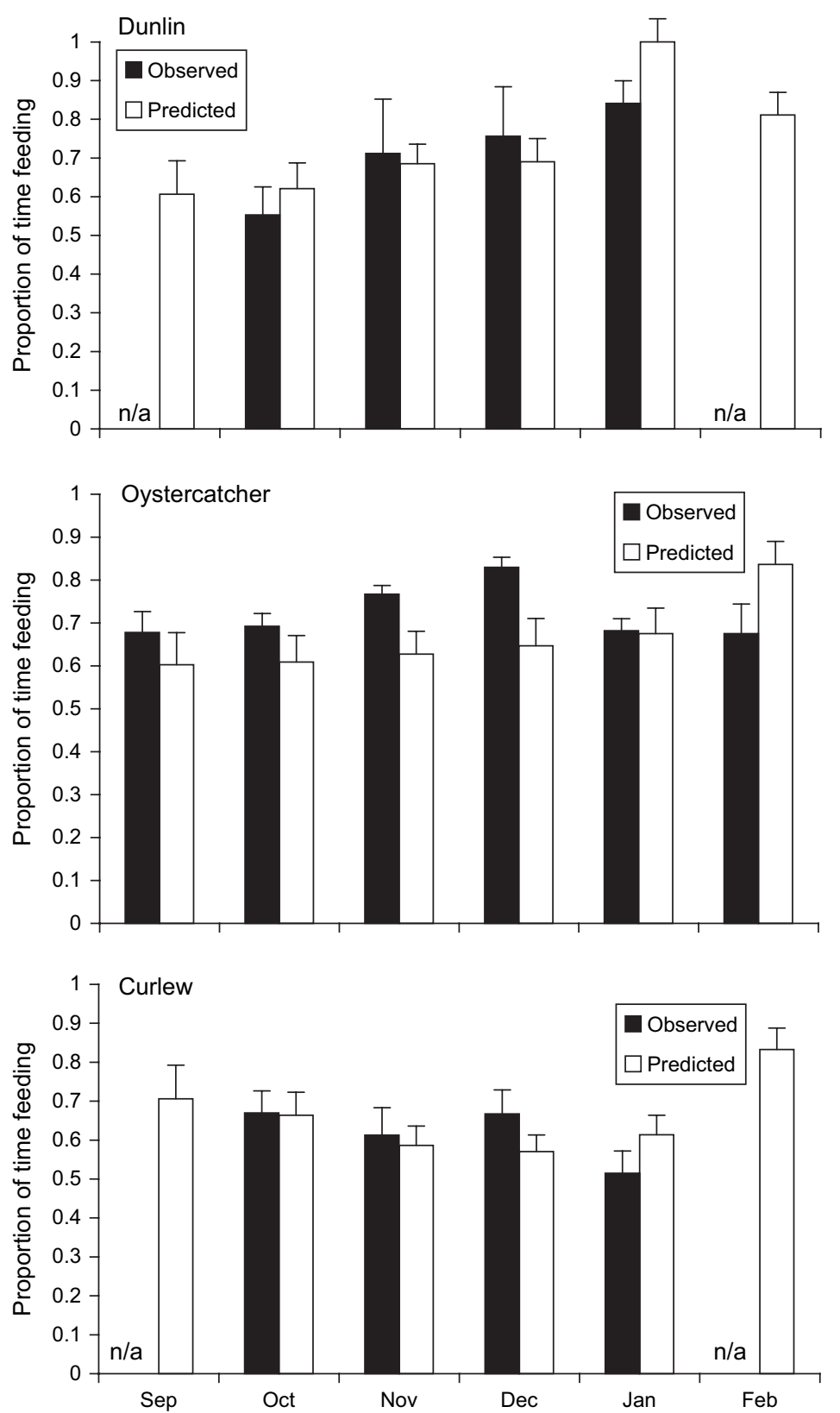

FIG. 4 Observed and model-predicted values for the proportion of time spent feeding throughout the winter. Bars are means with 95\% confidence limits. decrease when disturbance rates exceeded six events $\mathrm{h}^{-1}$, and oystercatcher survival when disturbance rates exceeded only one $\mathrm{h}^{-1}$. Dunlin survival was unaffected by disturbance within the Réserve because, unlike the other two species, they were able to feed outside the Réserve without being shot.

Dunlin survival decreased steadily with Spartina encroachment, particularly when habitat loss exceeded 100 ha (Fig. 8). At present rates of encroachment this level of habitat loss is likely to be reached in 5-10 years' time. When the increase in Spartina area exceeded 200 ha, oystercatcher and curlew survival also started to decrease as habitat was lost from patch 3. This level of habitat loss is likely to be reached in 10-20 years' time.

Dunlin were the most affected by any changes in sediment levels (Fig. 9). Dunlin survival increased when we increased patch heights, thus increasing the time available for feeding throughout the tidal cycle, and decreased significantly when we decreased patch heights. Oystercatcher and curlew survival were less seriously affected by changes in sediment levels, although oystercatcher survival became more variable when patch heights were raised or lowered by $>40 \mathrm{~cm}$ and curlew survival decreased when sediment levels were lowered or raised by $>80 \mathrm{~cm}$.

\section{Discussion}

We have addressed several management issues in the Baie de Somme in terms of the survival rates of three species of overwintering shorebirds. To do this, we parameterized an individual-based model using our own survey data and data 


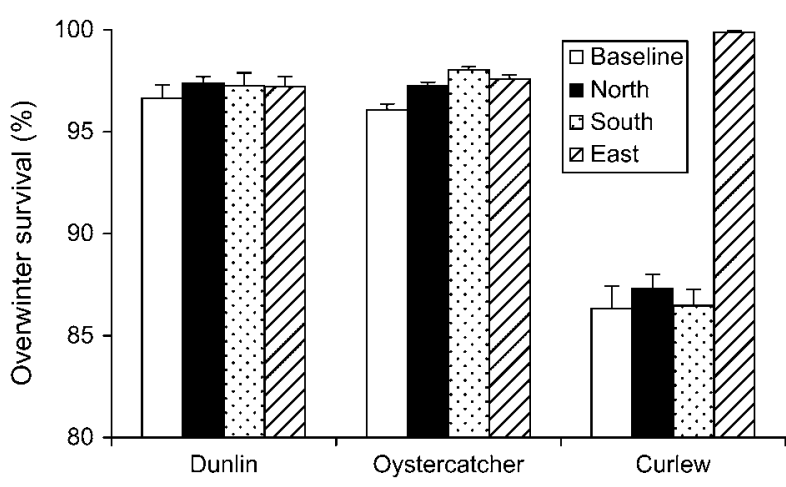

Fig. 5 The effect on shorebird overwinter survival of banning hunting on patches $1 \& 2$ (North), patch 8 (South) or on patches $6 \& 7$ (East). Baseline $=$ hunting allowed in all areas outside the Réserve Naturelle.

collected from the literature. We validated the model by comparing the distribution and the feeding activity of birds in the model with that observed at monthly intervals throughout the winter of 2001-2002. The distribution of model birds and the proportion of time spent feeding at low water were close to that observed for all three species throughout the winter. This gives us confidence in the model's predictions.
One of the most interesting features of the results was the buffering effect that hunting had on oystercatcher and curlew mortality. This was because, if birds were starving, there was a plentiful supply of food outside the Réserve Naturelle that they could exploit at the risk of being shot. This meant that the principal source of mortality for oystercatchers and curlew was being shot, and that more birds were shot when they were starving. However, it also meant that starving birds had a chance, albeit a risky one, of replenishing their reserves.

The model predicted that, if the area protected from hunting should be extended, protecting the area to the east of the estuary would most benefit shorebird survival. Protecting the north and south sides of the estuary benefited oystercatcher survival but protecting the east of the estuary not only benefited oystercatcher survival but also dramatically increased curlew survival. This was because the muddy patch adjacent to Les Molières saltmarsh (Chassehaut in the model) had the highest densities in the whole estuary of the main curlew prey, polychaete worms (Table 2). We suggest that, should any eventuality threaten curlew or oystercatcher survival in the Baie de Somme, one effective mitigating step would be to protect this part of the estuary from hunting. (a)
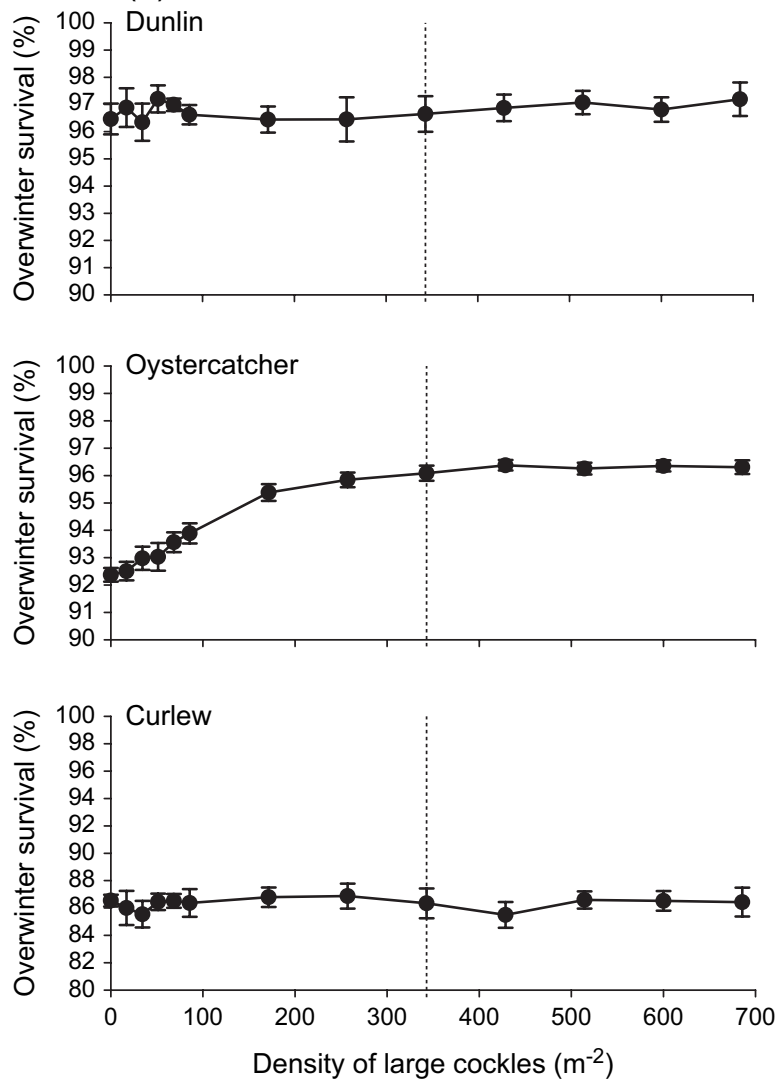

(b)
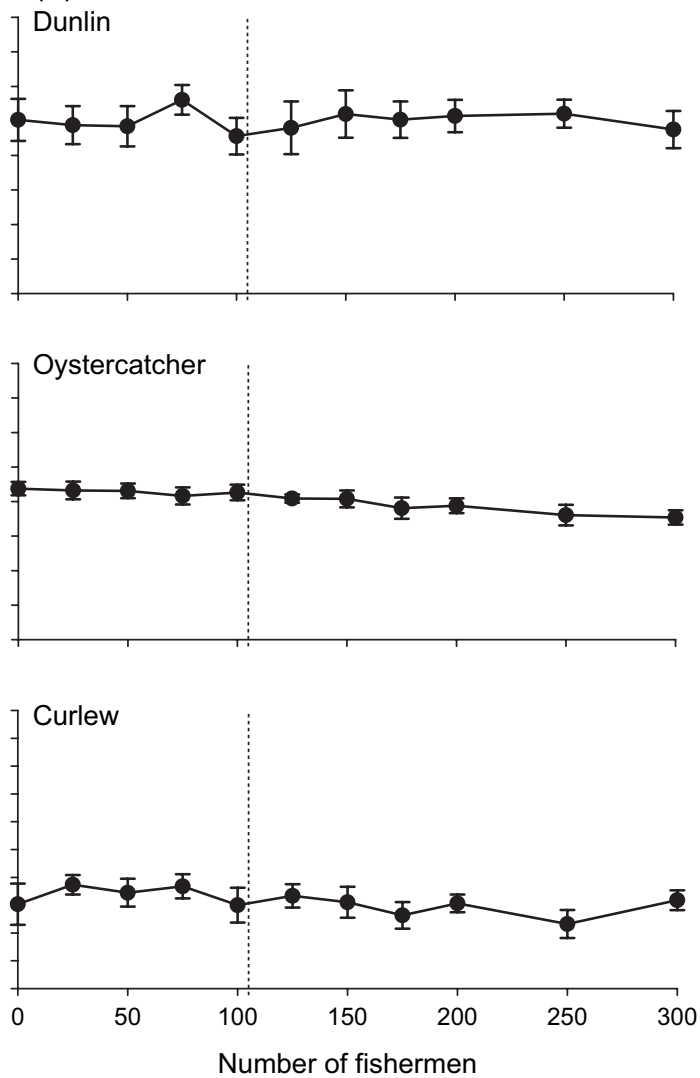

FIG. 6 The effect on shorebird overwinter survival of (a) reducing the density of cockle stocks ( $>15 \mathrm{~mm}$ in size) at the start of the winter, and (b) increasing the number of cockle fishermen allowed on the cockle beds each day. Dashed lines show present-day levels. 

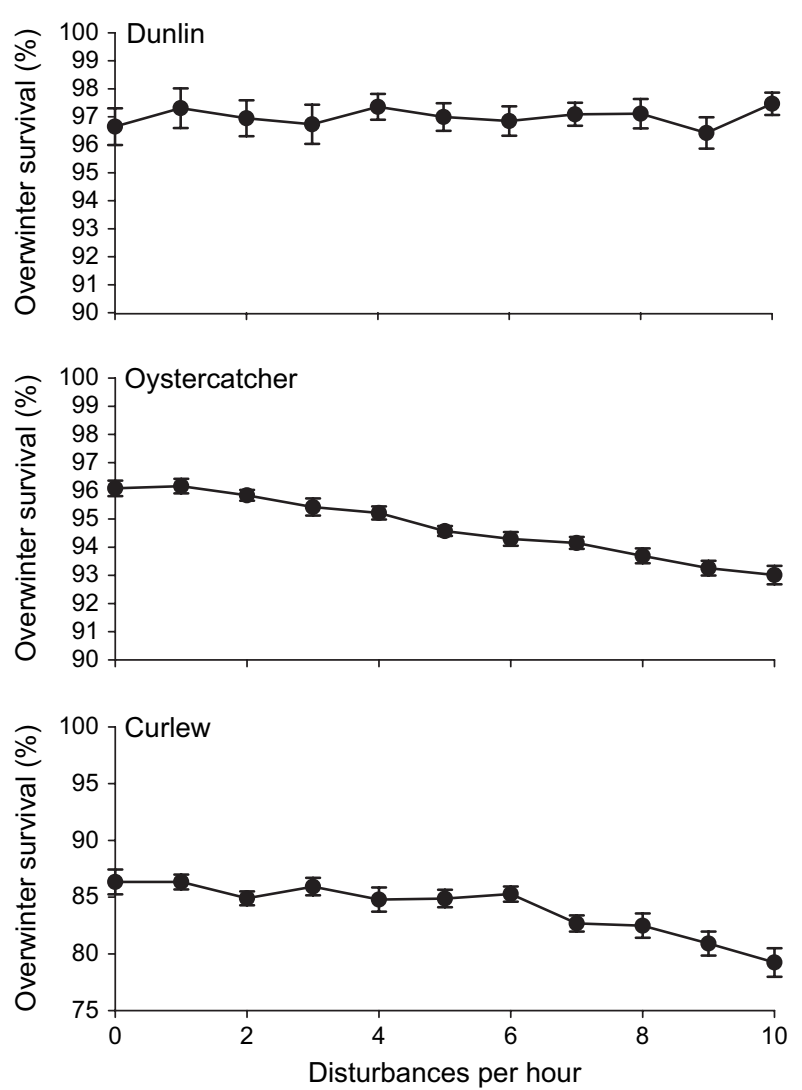

FIG. 7 The effect on shorebird overwinter survival of increasing the daily rate of disturbances within the Réserve Naturelle.

As oystercatchers eat commercially-sized shellfish, there is always likely to be a conflict between shellfishery management and shorebird conservation (Horwood \& GossCustard, 1977; Prater, 1981; Atkinson et al., 2003). Several studies have already used individual-based models to address the issue of oystercatcher survival and shellfishery management (Stillman et al., 2001; West et al., 2003; Caldow et al., 2004; Goss-Custard et al., 2004). In this study we have shown that, should cockle stocks fall below $250 \mathrm{~m}^{-2}$, current levels of cockle fishing could not be continued without seriously affecting oystercatcher survival. However, we have also shown that, with existing cockle stocks, existing fishing restrictions and average weather conditions, the number of cockle fishermen allowed in the Réserve Naturelle could be doubled without any deleterious effect on oystercatcher survival. This means not only that existing cockle stocks are sufficient to support both the oystercatcher population and the cockle industry in the Baie de Somme but also that the disturbance resulting from fishing has much less effect on oystercatcher survival than that resulting from recreational activities. This is because longer-term disturbance events, such as fishing, make birds avoid a feeding area altogether whilst short-term disturbance events, such as walkers, cause birds to take avoidance flight each time they are disturbed and so incur greater energetic costs.
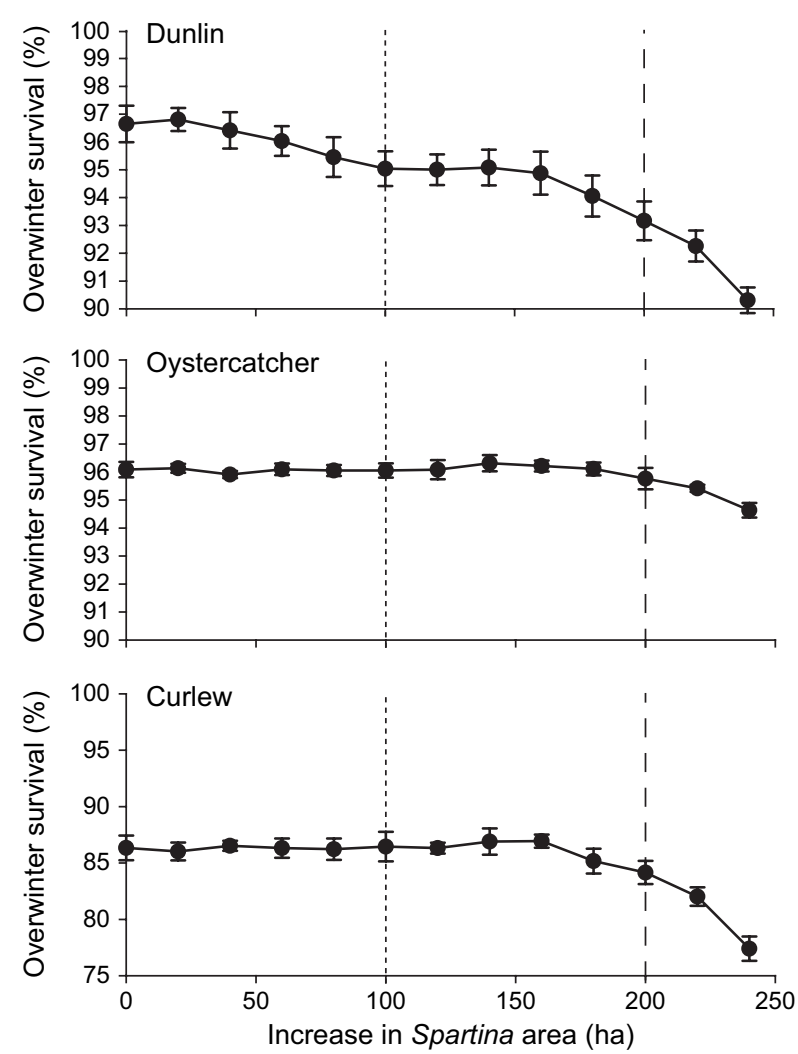

FIG. 8 The effect of Spartina encroachment on shorebird overwinter survival. The short-dashed line represents the potential increase in area in 5-10 years' time and the long-dashed line represents the potential increase in area in 10-20 years' time.

When we varied the rate of short-term disturbance events within the Réserve Naturelle, we found that curlew survival decreased when the number of disturbances exceeded six $\mathrm{h}^{-1}$ and that oystercatcher survival decreased when the number of disturbances exceeded only one $\mathrm{h}^{-1}$. This value for oystercatchers was similar to that obtained in a previous study using a different individual-based model (Goss-Custard et al., 2006a), which also showed that birds could only tolerate these rates of disturbance under good feeding conditions and during relatively mild weather. Should feeding conditions or winter weather deteriorate, reserve managers would need to minimize the amount of disturbance affecting feeding and roosting birds.

Another issue in the management of the Baie de Somme Réserve Naturelle is Spartina encroachment. Whilst Spartina marshes have their own conservation value (Gray \& Benham, 1990), Spartina encroachment removes feeding habitat for shorebirds such as dunlin (Goss-Custard \& Moser, 1988). Here we have shown that, even though dunlin can feed throughout the Baie de Somme without being shot, the present rate of Spartina encroachment in the north of the estuary will adversely affect dunlin survival within a period of only $10-20$ years.

Finally, we considered the effect on shorebird survival of changes in estuary sediment levels resulting either from 

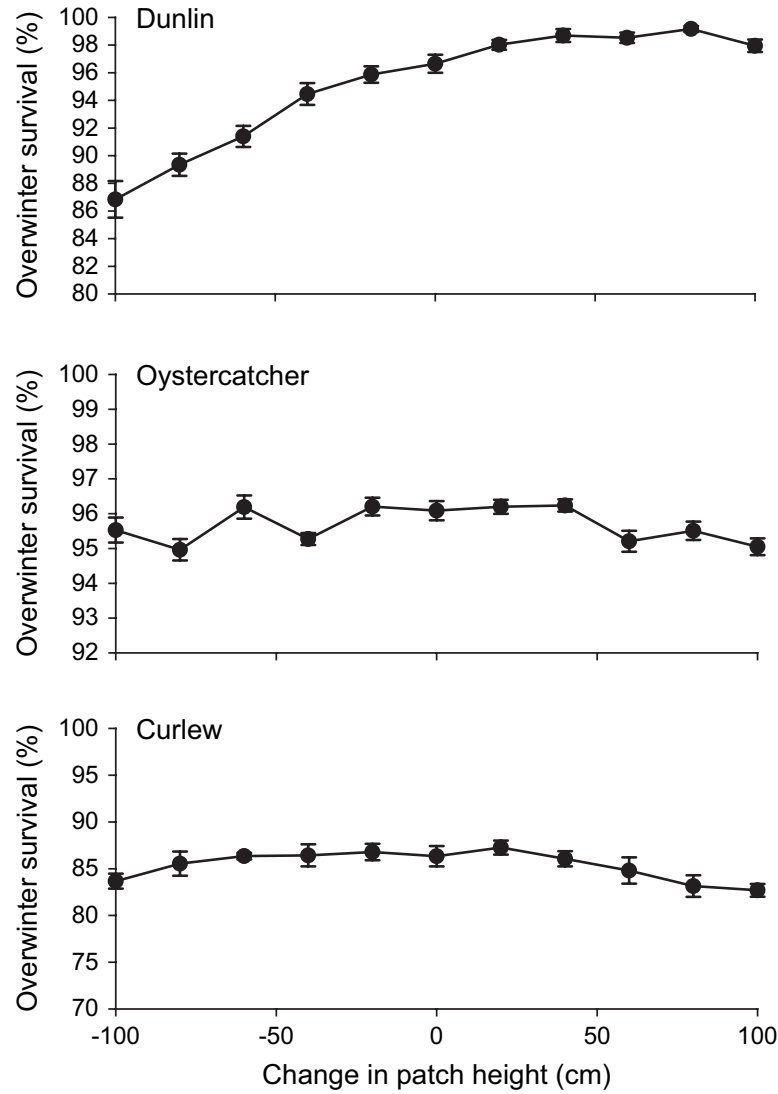

FIG. 9 The effect of changes in sediment levels on shorebird overwinter survival.

sedimentation or from sea-level rise. Oystercatcher and curlew survival were not greatly affected by either an increase or a decrease in the height of the intertidal flats. However, dunlin survival increased with increased patch height and decreased with decreased patch height. This indicates that the length of time for which inter-tidal flats are exposed in the Baie de Somme is more critical for dunlin than the other two species. However, the Baie de Somme is a macrotidal estuary and the intertidal flats are exposed for long periods during the tidal cycle (McClusky et al., 1994). This means that any reduction in exposure time resulting from, for example, sea-level rise, was not as critical for shorebird survival in the Baie de Somme as has been found on other estuaries (Durell et al., 2006). Nor does the process of sedimentation, which in any case may counterbalance any effect of sea-level rise, appear to offer any serious risk to shorebird survival.

The potential value of individual-based models is not widely recognized and many researchers are unfamiliar with their principles and their application (Grimm \& Railsback, 2005). Nonetheless, the demand from nature managers and policy makers for the advice that such models can give is likely to lead to much increased usage. Here we have shown how an individual-based model can be used to advise reserve managers in one particular site for one particular group of birds. However, we hope that, as such models become more widely deployed to a wider range of sites and a wider range of taxa, that general policy guidelines may emerge. For example, as shown here, shortterm disturbance events can, by incurring greater energetic costs, have a greater effect on survival than longer-term disturbance events. Such guidelines will enable managers to invest their resources more effectively in those management options with the most beneficial effect.

Reserve managers in the Baie de Somme have so far used our results to support two main changes in their management regime. Firstly, they have brought forward the timing of the shellfishing season so that shorebirds are less disturbed in late winter when their energetic requirements are highest. Secondly, they have implemented measures (mainly ploughing) to halt and reverse the spread of Spartina in certain parts of the estuary. Only in the case of sedimentation, which is also considered to be a threat to shorebird survival, have they been unable to effect any change. This is mostly due to the cost involved in removing so much sand and also to the lack of any other technical solution.

\section{Acknowledgements}

We are very grateful to Philip Stephens and Phil Atkinson for their comments on an earlier version of this manuscript.

\section{References}

Atrinson, P.W., Clark, N.A., Bell, M.C., Dare, P.J., Clark, J.A. \& IRELAND, P.L. (2003) Changes in commercially fished shellfish stocks and shorebird populations in the Wash, England. Biological Conservation, 114, 127-141.

Caldow, R.W.G., Beadman, H.A., McGrorty, S., Stillman, R.A., Goss-Cust ard, J.D., Durell, S.E.A. Le V. Dit et al. (2004) A behavior-based modeling approach to reducing shorebirdshellfish conflicts. Ecological Applications, 14, 1411-1427.

Cramp, S. \& Simmons, K.E.L. (eds) (1983) Handbook of the Birds of Europe, the Middle East and North Africa. The Birds of the Western Palearctic, Vol. III. Oxford University Press, Oxford, UK.

Cresswell, W. \& Whitfield, D.P. (1994) The effects of raptor predation on wintering wader populations at the Tyninghame estuary, southeast Scotland. Ibis, 136, 223-232.

Davidson, N.C., Lafoley, D. d'A., Doody, J.P., Way, L.S., Gordon, J., Key, R. et al. (1991) Nature Conservation and Estuaries in Britain. Nature Conservancy Council, Peterborough, UK.

DesPREZ, M. (1995) Etude sur le fonctionnement et la productivité biologique de l'écosysteme Baie de Somme. GEMEL, St Valery, France.

Durell, S.E.A. Le V. Dit, McGrorty, S., West, A.D., Clarke, R.T., Goss-Custard, J.D. \& Stillman, R.A. (2005a) A strategy for baseline monitoring of estuary Special Protection Areas. Biological Conservation, 121, 289-301.

Durell, S.E.A. Le V. Dit, Stillman, R.A., Caldow, R.W.G, McGrorty, S., West, A.D. \& Humphreys, J. (2006) Modelling 
the effect of environmental change on shorebirds: a case study on Poole Harbour, UK. Biological Conservation, 131, 459-473.

Durell, S.E.A. Le V. Dit, Stillman, R.A., Triplet, P., Aulert, C., Ono dit Biot, D., Bouchet, A. et al. (2005b) Modelling the efficacy of proposed mitigation areas for shorebirds: a case study on the Seine estuary, France. Biological Conservation, 123, 67-77.

Goss-Custard, J.D. \& Moser, M.E. (1988) Rates of change in the number of dunlin, Calidris alpina, wintering in British estuaries in relation to the spread of Spartina anglica. Journal of Applied Ecology 25, 95-109.

Goss-Custard, J.D., Stillman, R.A., West, A.D., Caldow, R.W.G., Triplet, P., Durell, S.E.A. Le V. Dit et al. (2004) When enough is not enough: shorebirds and shellfishing. Proceedings of the Royal Society of London, Series B: Biological Sciences, 271, 233-237.

Goss-Custard, J.D., Triplet, P., Sueur, F. \& West, A.D. (2006a) Critical thresholds of disturbance by people and raptors in foraging wading birds. Biological Conservation 127, 88-97.

Goss-Custard, J.D., West, A.D., Yates, M.G., Caldow, R.W.G., Stillman, R.A., Castilla, J. et al. (2006b) Intake rates and the functional response in shorebirds (Charadriiformes) eating macro-invertebrates. Biology Reviews, 81, 1-29.

Gray, A.J. \& Benham, P.E.M. (eds) (1990) Spartina anglica - A Research Review. HMSO, London, UK.

Grimm, V. \& Railsback, S.F. (2005) Individual-based Modelling and Ecology. Princeton University Press, Princeton, USA.

Horwood, J.W. \& Goss-Custard, J.D. (1977) Predation by the oystercatcher, Haematopus ostralegus L. in relation to the cockle Cerastoderma edule L. fishery in the Burry Inlet, South Wales. Journal of Applied Ecology, 14, 139-158.

McClusky, D.S., Desprez, M., Elkaim, B. \& Duhamel, S. (1994) The inner estuary of the Baie de Somme. Estuarine Coastal and Shelf Science, 38, 313-318.

Prater, A.J. (1981) Estuary Birds of Britain and Ireland. Poyser, Calton, UK.

Sogreah/EDF (1995) Etude sédimentologique de la Baie de Somme. Synthèse des données naturelles, analyse des mécanismes d'évolution sédimentaire et paramètres à retenir pour la modèle réduit. Conseil General de la Somme, DDE de la Somme, France.

Stillman, R.A., Goss-Custard, J.D., West, A.D., Durell, S.E.A. Le V. dit, McGrorty, S., Caldow, R.W.G. et al. (2001) Predicting shorebird mortality and population size under different regimes of shellfishery management. Journal of Applied Ecology, $38,857-868$.

Stillman, R.A., West, A.D., Durell, S.E.A. Le V. Dit, Caldow, R.W.G., McGrorty, S., Yates, M.G. et al. (2005a) Estuary Special Protection Areas - Establishing Baseline Targets for Shorebirds. Final Report. English Nature, Peterborough, UK.
Stillman, R.A., West, A.D., Goss-Custard, J.D., McGrorty, S., Frost, N.J., Morrisey, D.J. et al. (2005b) Predicting site quality for shorebird communities: a case study on the Humber estuary, UK. Marine Ecology Progress Series, 305, 213-217.

Stroud, D.A., Mudge, G.P. \& Pienkowski, M.W. (1990) Protecting Internationally Important Bird Sites. Nature Conservancy Council, Peterborough, UK.

Sueur, F. \& Triplet, P. (1999) Les Oiseaux de la Baie de Somme. SMACOPI/GOP/CDL/RNBS, Abbeville, France.

Triplet, P., Bacquet, S., Lengignon, A., Oget, E. \& Fagot, C. (1999) Effets de dérangements sur l'Huitrier-pie (Haematopus ostralegus) en Baie de Somme. Gibier Faune Sauvage, 15, 45-64.

Triplet, P., Méquin, N., Prévost, A., Erlinger, D. \& Sueur, F. (2003) Rythme d'activité diurne de l'Huîtrier-pie Haematopus ostralegus, du Courlis cendré Numenius arquata et du Bécasseau variable Calidris alpina en Baie de Somme. Alauda, 71, 459-468.

Triplet, P. \& Rousseau, S. (2001) Plan de gestion de la Réserve Naturelle de la Baie de Somme 2001-2005. SMACOPI, Abbeville, France.

West, A.D., Goss-Custard, J.D., Durell, S.E.A. Le V. Dit \& S TILlman, R.A. (2005) Maintaining estuary quality for shorebirds: towards simple guidelines. Biological Conservation, 123, 211-224.

West, A.D., Goss-Custard, J.D., McGrorty, S., Stillman, R.A., Durell, S.E.A. Le V. Dit, Stewart, B. et al. (2003) The Burry shellfishery and oystercatchers: using a behaviour-based model to advise on shellfishery management policy. Marine Ecology Progress Series, 248, 279-292.

\section{Biographical sketches}

SARAH DURELl worked for nearly 30 years as a wader population ecologist and was closely involved in the development and use of Centre for Ecology and Hydrology (CEH) models to predict the effect of environmental change on shorebirds. RICHARD STILLMAN is an applied ecologist and modeller who designed and wrote the $\mathrm{CEH}$ individual-based shorebird model. He is currently using the model to investigate environmental concerns for a wider range of study species. Patrick Triplet has been studying waders for the last 30 years and is the scientific manager of the Baie de Somme Nature Reserve. Michel Desprez, Cédric Fagot and Nicolas Loquet are benthic invertebrate biologists who were responsible for surveying the invertebrate populations of the Baie de Somme. Fr A C C O IS SUE UR is the Chairman of the Ornithological Society of Picardy. JoHn Goss CUSTARD is a shorebird ecologist who was the originator of the Centre for Ecology and Hydrology shorebird models and the driving force behind the development and application of the model used in this study. 